REVIEW ARTICLE

\title{
Cancer and life-history traits: lessons from host-parasite interactions
}

\author{
BEATA UJVARI ${ }^{1}$, CHRISTA BECKMANN ${ }^{1}$, PETER A. BIRO ${ }^{1}$, AUDREY ARNAL ${ }^{2}$, \\ AURELIE TASIEMSKI ${ }^{3}$, FRANCOIS MASSOL ${ }^{3}$, MICHEL SALZET ${ }^{4}$, \\ FREDERIC MERY ${ }^{5}$, CELINE BOIDIN-WICHLACZ ${ }^{3}$, DOROTHEE MISSE ${ }^{2}$, \\ FRANCOIS RENAUD ${ }^{2}$, MARION VITTECOQ ${ }^{6}$, TAZZIO TISSOT ${ }^{2}$, \\ BENJAMIN ROCHE ${ }^{2,7}$, ROBERT POULIN ${ }^{8}$ and FREDERIC THOMAS ${ }^{2}$ \\ ${ }^{1}$ School of Life and Environmental Sciences, Centre for Integrative Ecology, Deakin University, Geelong, VIC, 3216. \\ Australia \\ ${ }^{2}$ CREEC/MIVEGEC, UMR IRD/CNRS/UM 5290, 911 Avenue Agropolis, BP 64501, 34394 Montpellier Cedex 5, \\ France \\ ${ }^{3}$ UMR CNRS 8198, Unité Evolution, Ecologie et Paléontologie, Université de Lille1, France \\ ${ }^{4}$ Laboratoire Protéomique, Réponse Inflammatoire et Spectrométrie de Masse (PRISM) INSERM U1192-Université \\ Lille, 1-FR 3688, CNRS, France \\ ${ }^{5}$ Evolution, Génomes, Comportement \&̊ Ecologie, CNRS, IRD, Univ.Paris-Sud, Université Paris Saclay, 91198 Gif-sur- \\ Yvette \\ ${ }^{6}$ Centre de Recherche de la Tour du Valat, le Sambuc, 13200 Arles, France \\ ${ }^{7}$ International Center for Mathematical and Computational Modelling of Complex Systems (UMI IRD/UPMC \\ UMMISCO), 32 Avenue Henri Varagnat, 93143 Bondy Cedex, France \\ ${ }^{8}$ Department of Zoology, University of Otago, PO BOX 56, New-Zealand
}

(Received 28 October 2015; revised 21 December 2015; accepted 6 Fanuary 2016; first published online 18 February 2016)

SUMMARY

Despite important differences between infectious diseases and cancers, tumour development (neoplasia) can nonetheless be closely compared to infectious disease because of the similarity of their effects on the body. On this basis, we predict that many of the life-history ( $\mathrm{LH})$ responses observed in the context of host-parasite interactions should also be relevant in the context of cancer. Parasites are thought to affect LH traits of their hosts because of strong selective pressures like direct and indirect mortality effects favouring, for example, early maturation and reproduction. Cancer can similarly also affect LH traits by imposing direct costs and/or indirectly by triggering plastic adjustments and evolutionary responses. Here, we discuss how and why a LH focus is a potentially productive but under-exploited research direction for cancer research, by focusing our attention on similarities between infectious disease and cancer with respect to their effects on LH traits and their evolution. We raise the possibility that LH adjustments can occur in response to cancer via maternal/paternal effects and that these changes can be heritable to (adaptively) modify the LH traits of their offspring. We conclude that LH adjustments can potentially influence the transgenerational persistence of inherited oncogenic mutations in populations

Key words: Cancer, evolutionary ecology, life-history traits, parasites, plasticity.

\section{INTRODUCTION}

Cancer, a leading cause of human death worldwide, occurs across phylogenetical lineages, suggesting that cancer may have been present throughout the evolutionary history of multicellular organisms (Merlo et al. 2006; Aktipis and Nesse, 2013; Nunney, 2013). Despite the widespread existence of cancer in the animal kingdom, oncology and other sciences have until very recently developed in relative isolation.

* Corresponding author. CREEC/ MIVEGEC, UMR IRD/CNRS/UM 5290, 911 Avenue Agropolis, BP 64501, 34394 Montpellier Cedex 5, France. Phone +33 (0)4 674163 18. Fax: +33 (0)4 674163 30. E-mail: Frederic.thomas2@ird.fr
This is unfortunate given that links between these disciplines have the reciprocal potential to reveal new directions for research and perspectives as well as proposing new therapeutic solutions. For example, it is increasingly acknowledged that applying ecological and evolutionary theory to cancer allows researchers to improve techniques to control malignant progression and prevent therapeutic failures (Aktipis and Nesse, 2013; Thomas et al. 2013; Rozhok and DeGregori, 2015). In addition, considering the ecological contexts in which cancers occur in wildlife improves our understanding of the evolution of the pathology itself, as well as to its theoretical potential to shape organism traits (Kokko and Hochberg, 2015). Ecologists have also proposed that oncogenic 
phenomena have important influences on shaping animal behaviour, life history and even ecosystem functioning (Vittecoq et al. 2013, 2015).

Here, we propose a research direction deserving of more attention concerning life-history (LH) responses displayed by animals in the face of cancer risks and/or malignant progression. The primary reasons this topic has until now been poorly investigated are because it is often assumed that: (i) cancer in wildlife is rare; and (ii) adaptive responses against cancer are unlikely to evolve because cancer is a post-reproductive disease (see Vittecoq et al. 2013). However, evidence increasingly indicates that cancer is in fact likely to be common in wildlife, and has been documented in a diverse array of taxa from invertebrates to large mammals (Table 1). Furthermore, cancer can increase the risk that animals die early in life due to predation or parasitism (Martineau et al. 2002; McAloose and Newton, 2009). For example, oncogenic phenomena in wildlife (as in humans) encompass a large range of more or less malignant tumours, ranging from benign neoplasms to metastatic malignancies that induce various consequences on health and vigour, such as early death and decreased reproductive potential (Table 1; see also Vittecoq et al. 2013). As a result of these negative effects, animals can become more susceptible to interspecific interactions (especially predation and parasitism) that result in death prior to the end of the reproductive period. Together, these observations suggest that natural selection should favour adaptations that prevent cancer-induced reductions in fitness, just as we would expect for any other infections (Thomas et al. 2009). Thus, we draw on the literature related to parasitism and its effects on $\mathrm{LH}$ traits to guide us towards profitable avenues for cancer research. Whereas proximate mechanisms guarding against cancer, such as lower somatic mutation rates and redundancy of tumour suppressor genes, are currently being extensively studied in some wildlife species (Caulin and Maley, 2011; Roche et al. 2012), thus far much less attention has been paid to other traits, such as LH adaptations.

\section{Infection and cancer in multicellular organisms}

Importantly, cancer cells not only act similarly to parasites by diverting energy and resources from other vital functions of the host, but also a substantial proportion of malignancies are caused by infections (ca. 20\% of human cancers; Ewald and Swain Ewald, 2015). Thus, infections could contribute to cancer directly or indirectly. Direct initiation results from pathogens (particularly intracellular parasites) altering cellular regulatory mechanisms (e.g. apoptosis and cell-cycle arrest) and cell proliferation rates, and therefore breaking down cellular barriers that would otherwise prevent oncogenesis. Infection-induced inflammatory responses may also result in increased mutation rates and compromised proliferation signals, and concomitantly indirectly initiate malignant transformations (reviewed in Ewald and Swain Ewald, 2012, 2013). Although protozoans (e.g. Plasmodium falciparum, Molyneux et al. 2012), bacteria (e.g. Helicobacter pylori, Mager 2006; Ewald and Swain Ewald, 2014) and trematodes (e.g. Schistosoma haemotobium, Mostafa et al. 1999; Ewald and Swain Ewald, 2014) have all been shown to directly or indirectly cause malignancies, viruses are the most frequent sources of infection-induced cancers (reviewed by Ewald and Swain Ewald, 2015). While oncogenic pathogens and their induced malignancies are well documented in humans and domestic animals, they are less well recorded in undomesticated captive animals, and are largely undetected in nature. Ewald and Swain Ewald (2015) have proposed several explanations for why cancer is rarely found in natural populations: (1) although benign neoplasms occur pervasively in multicellular organisms they rarely transition to detectable malignant tumours; (2) reduced survival due to malignancy [as a direct (detrimental to health) or indirect (increased predation) consequence of cancer] hinders detectability; and (3) diagnostics and evaluation of malignancy are inconsistent across species. The full scope of infection-induced cancers is still not known for any multicellular species, but interestingly infection-induced cancers are known to occur at young ages (e.g. cervical cancer in humans).

Cancer, being induced by pathogens or acting analogously to parasites, or both, clearly has a major impact on host' LH traits. We next discuss cancer as selective force on host LH traits.

\section{Why should cancer influence LH traits?}

Cancer, both solid tumours and blood cancers, can be thought of as a developing species that behaves in a manner akin to parasites (Duesberg et al. 2011). As far as host LH traits are concerned, parasites likely play an important role in their evolution because they often impose important selective pressures on the host (Michalakis and Hochberg, 1994). Similarly, cancer cells depend on their hosts for sustenance, proliferating inside their bodies, exploiting them for energy and resources, and thereby impairing their health and fitness. Based on these similarities, it is predicted that several of the responses that have evolved in the context of host-parasite interactions should also be relevant in the context of cancer (Vittecoq et al. 2013). Evolutionary theory on host-parasite interactions postulates that host species should also be under selective pressures to avoid the source of the pathology in the first instance (e.g. Hart, 1994), then prevent its progression once infected, and finally alleviate the fitness costs if further development is not preventable (Thomas et al. 2009). 


\begin{tabular}{|c|c|c|c|c|c|c|}
\hline Common name & Latin name & Context and prevalence & Cancer type & Factors favouring cancer & $\begin{array}{l}\text { Potential impact on host LH } \\
\text { traits }\end{array}$ & Reference \\
\hline \multicolumn{7}{|l|}{ Invertebrate } \\
\hline Hydra & $\begin{array}{l}\text { Pelmatohydra } \\
\text { robusta }\end{array}$ & $\begin{array}{l}\text { Laboratory population, } \\
\text { unknown }\end{array}$ & Undetermined & Genetic predisposition & $\begin{array}{l}\text { Reduced population growth } \\
\text { rate, reduced capacity of egg } \\
\text { production. Tumour-bearing } \\
\text { polyps have significantly } \\
\text { reduced fitness }\end{array}$ & $\begin{array}{l}\text { Domazet-Loso } \\
\text { et al. }(2014)\end{array}$ \\
\hline Blue mussel & Mytilus trossulus & $\begin{array}{l}\text { Cultured and wild } \\
\text { populations, up to } 40 \% \\
\text { in northeast Pacific }\end{array}$ & Haemic neoplasia & Unknown & $\begin{array}{l}\text { Increased mortality. } \\
\text { Haemocytes showing signifi- } \\
\text { cantly less phagocytic capacity } \\
\text { leading to reduced immune } \\
\text { function and mortality }\end{array}$ & $\begin{array}{l}\text { Ciocan } \text { et al. } \\
\text { (2006); Ciocan } \\
\text { and Sunila (2005); } \\
\text { Galimany and } \\
\text { Sunila (2008) }\end{array}$ \\
\hline $\begin{array}{l}\text { Soft-shell } \\
\text { clam }\end{array}$ & Mya arenaria & $\begin{array}{l}\text { East coast of North } \\
\text { America, up to } 100 \% \text { in } \\
\text { affected areas }\end{array}$ & Haemic neoplasia & $\begin{array}{l}\text { Retrotransposon } \\
\text { (Steamer) }\end{array}$ & $\begin{array}{l}\text { Increased mortality. } \\
\text { Haemocytes showing signifi- } \\
\text { cantly less phagocytic capacity } \\
\text { leading to reduced immune } \\
\text { function and mortality }\end{array}$ & $\begin{array}{l}\text { Metzger et al. } \\
(2015)\end{array}$ \\
\hline $\begin{array}{l}\text { Common } \\
\text { fruit fly }\end{array}$ & $\begin{array}{l}\text { Drosophila } \\
\text { melanogaster }\end{array}$ & $\begin{array}{l}\text { Laboratory population, } \\
19 \% \text { in } 5 \text {-week old } \\
\text { males }\end{array}$ & Gut and testis tumours & Unknown & $\begin{array}{l}\text { Altered egg production, females } \\
\text { with cancer reach peak ovipos- } \\
\text { ition earlier than healthy } \\
\text { females }\end{array}$ & $\begin{array}{l}\text { Salomon and } \\
\text { Jackson (2008) }\end{array}$ \\
\hline \multicolumn{7}{|c|}{ The } \\
\hline $\begin{array}{l}\text { Yellow sea } \\
\text { horse \& } \\
\text { weedy sea } \\
\text { dragon }\end{array}$ & $\begin{array}{l}\text { Hippocampus } \\
\text { kuda छे } \\
\text { Phyllopteryx } \\
\text { taeniolatus }\end{array}$ & $\begin{array}{l}\text { Captive (zoo), } 9 \text { out of } \\
172 \text { syngnathids ana- } \\
\text { lysed, mostly adult } \\
\text { males }\end{array}$ & $\begin{array}{l}\text { Cardiac rhabdomyosarcoma, } \\
\text { renal adenocarcinoma, renal } \\
\text { adenoma, lymphomas, exo- } \\
\text { crine pancreatic carcinoma, } \\
\text { intestinal carcinoma }\end{array}$ & Unknown & $\begin{array}{l}\text { Cancer potentially impacts } \\
\text { feeding and predator evasion, } \\
\text { as well as might reduce repro- } \\
\text { ductive output by primarily } \\
\text { affecting males (male sea horses } \\
\text { being the carers of eggs) }\end{array}$ & LePage et al. (2012) \\
\hline Coral trout & $\begin{array}{l}\text { Plectropomus } \\
\text { leopardus }\end{array}$ & $\begin{array}{l}\text { Free-living, } 15 \% \text { in part } \\
\text { of the Great Barrier } \\
\text { Reef }\end{array}$ & Melanomas & $\begin{array}{l}\text { Genetic predisposition - } \\
\text { potentially associated } \\
\text { with hybridization with } \\
\text { another Plectropomus } \\
\text { species }\end{array}$ & $\begin{array}{l}\text { Fish with cancer are potentially } \\
\text { less active and feed less }\end{array}$ & Sweet et al. (2012) \\
\hline \multicolumn{7}{|l|}{ Amphibians } \\
\hline $\begin{array}{l}\text { African } \\
\text { clawed frog }\end{array}$ & Xenopus laevis & $\begin{array}{l}\text { Laboratory population, } \\
5 \% \text { in the studied } \\
\text { population }\end{array}$ & $\begin{array}{l}\text { Various forms the most } \\
\text { common being hepatomas, } \\
\text { ovarian tumours and } \\
\text { teratomas }\end{array}$ & $\begin{array}{l}\text { Various, e.g. virus, bac- } \\
\text { terium } \\
\text { (Myocobacterium } \\
\text { marinum) }\end{array}$ & $\begin{array}{l}\text { In some cases diseased indivi- } \\
\text { duals stop feeding and die. } \\
\text { Ovarian tumours might impair } \\
\text { reproduction }\end{array}$ & $\begin{array}{l}\text { Balls (1962); Goyos } \\
\text { and Robert } \\
\text { (2009); Hardwick } \\
\text { and Philpott } \\
\text { (2015) }\end{array}$ \\
\hline \multicolumn{7}{|l|}{ Reptiles } \\
\hline $\begin{array}{c}\text { Green } \\
\text { turtle }\end{array}$ & Chelonia mydas & $\begin{array}{l}\text { Free-living, up to } 58 \% \text { in } \\
\text { the Hawaiian } \\
\text { archipelago }\end{array}$ & $\begin{array}{l}\text { Tumours of the skin, flippers, } \\
\text { periocular tissues, carapace } \\
\text { and plastron; nodules can also } \\
\text { be found in all internal organs }\end{array}$ & Herpes virus infection & $\begin{array}{l}\text { High mortality rates, impaired } \\
\text { movements. Rapidly growing } \\
\text { tumours disrupt the turtle's } \\
\text { biologic functions (swimming, } \\
\text { diving), predator evasion and } \\
\text { feeding }\end{array}$ & $\begin{array}{l}\text { Brill et al. (1995); } \\
\text { Chaloupka et al. } \\
\text { (2009); Page- } \\
\text { Karjian et al. } \\
\text { (2014) }\end{array}$ \\
\hline
\end{tabular}




\begin{tabular}{|c|c|c|c|c|c|c|}
\hline Common name & Latin name & Context and prevalence & Cancer type & Factors favouring cancer & $\begin{array}{l}\text { Potential impact on host LH } \\
\text { traits }\end{array}$ & Reference \\
\hline $\begin{array}{l}\text { Egyptian } \\
\text { mastigure }\end{array}$ & $\begin{array}{l}\text { Uromastyx } \\
\text { aegyptius }\end{array}$ & $\begin{array}{l}\text { Captive (zoo), } 53 \% \text { in the } \\
\text { studied population }\end{array}$ & Multicentric lymphomas & Unknown & $\begin{array}{l}\text { High mortality rate. } \\
\text { Lymphomas impair feeding, } \\
\text { increase parasite burden and } \\
\text { cause organ failure }\end{array}$ & $\begin{array}{l}\text { Gyimesi et al. } \\
\text { (2005) }\end{array}$ \\
\hline \multicolumn{7}{|c|}{ 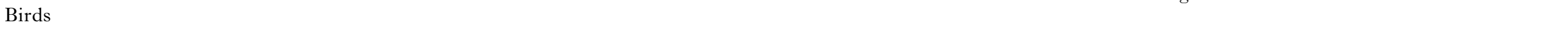 } \\
\hline Rock dove & Columba livia & $\begin{array}{l}\text { Laboratory population, } \\
34 \% \text { in the studied } \\
\text { population }\end{array}$ & $\begin{array}{l}\text { Various forms, the three most } \\
\text { frequent cancers are semino- } \\
\text { mas, thyroid adenomas and } \\
\text { lymphomas }\end{array}$ & Unknown & $\begin{array}{l}\text { Adenocarcinomas of the female } \\
\text { reproductive tracts and semi- } \\
\text { nomas of testicles might impair } \\
\text { reproduction }\end{array}$ & $\begin{array}{l}\text { Shimonohara et al. } \\
\text { (2012) }\end{array}$ \\
\hline $\begin{array}{l}\text { Domestic } \\
\text { chicken }\end{array}$ & Gallus gallus & $\begin{array}{l}\text { Breeding stocks, tumour } \\
\text { commonly causes } \geqslant 1 \%- \\
2 \% \text { mortality of birds, } \\
\text { with occasional losses of } \\
\geqslant 20 \%\end{array}$ & Lymphoid leucosis & Avian leucosis virus & $\begin{array}{l}\text { Subclinical infection decreases } \\
\text { egg production and quality, } \\
\text { and hence reproduction }\end{array}$ & Dunn (2013) \\
\hline \multicolumn{7}{|l|}{ Mammals } \\
\hline $\begin{array}{l}\text { Tasmanian } \\
\text { devil }\end{array}$ & $\begin{array}{l}\text { Sarcophilus } \\
\text { harrisii }\end{array}$ & $\begin{array}{l}\text { Free-living, up to } 80 \% \text { in } \\
2-3 \text { year-old } \\
\text { individuals }\end{array}$ & Tasmanian DFTD & Low genetic variation & $\begin{array}{l}\text { High mortality rates, tumours } \\
\text { on head impair vision and } \\
\text { feeding. DFTD spreads via } \\
\text { social interactions, primarily } \\
\text { during mating. High mortality } \\
\text { rates at reproductive age caused } \\
\text { shift in reproductive strategy to } \\
\text { semelparous from iteroparous }\end{array}$ & $\begin{array}{l}\text { McCallum et al. } \\
\text { (2007) }\end{array}$ \\
\hline $\begin{array}{l}\text { Santa } \\
\text { Catalina } \\
\text { Island fox }\end{array}$ & $\begin{array}{l}\text { Urocyon littoralis } \\
\text { catalinae }\end{array}$ & $\begin{array}{l}\text { Population living on } \\
\text { Santa Catalina Island, } \\
48 \cdot 9 \% \text { of dead foxes } \\
\text { examined from } 2001 \text { to } \\
2008,52 \cdot 2 \% \text { randomly } \\
\text { sampled live mature } \\
\text { animals }\end{array}$ & $\begin{array}{l}\text { Ceruminous gland dysplasia } \\
\text { and hyperplasia }\end{array}$ & $\begin{array}{l}\text { Indirectly caused by ear } \\
\text { mite (Otodectes cynotis) } \\
\text { infection }\end{array}$ & $\begin{array}{l}\text { The gross proliferative lesions } \\
\text { and invasive carcinomas } \\
\text { infiltrating adjacent bones may } \\
\text { impair hearing and hence the } \\
\text { hunting ability of the animals }\end{array}$ & $\begin{array}{l}\text { Vickers } \text { et al. } \\
\text { (2015); Moriarty } \\
\text { et al. (2015) }\end{array}$ \\
\hline Beluga & $\begin{array}{l}\text { Delphinapterus } \\
\text { leucas }\end{array}$ & $\begin{array}{l}\text { Free-living, } 27 \% \text { of the } \\
\text { adults found dead in } \\
\text { St. Lawrence estuary }\end{array}$ & $\begin{array}{l}\text { Various forms, most frequent } \\
\text { cancers are adenocarcinoma } \\
\text { of the intestine and stomach. } \\
\text { Ovarian cancers in females }\end{array}$ & $\begin{array}{l}\text { Probable role of the } \\
\text { polycyclic aromatic } \\
\text { hydrocarbons found in } \\
\text { beluga's prey }\end{array}$ & $\begin{array}{l}\text { High mortality rates. Intestinal } \\
\text { carcinomas alter nutrition ab- } \\
\text { sorption, ovarian tumours } \\
\text { might impair reproduction }\end{array}$ & $\begin{array}{l}\text { Martineau et al. } \\
\text { (2002) }\end{array}$ \\
\hline $\begin{array}{l}\text { California } \\
\text { sea lion }\end{array}$ & $\begin{array}{l}\text { Zalophus } \\
\text { californianus }\end{array}$ & $\begin{array}{l}\text { Free-living, } 18-25 \% \text { of } \\
\text { animals examined post- } \\
\text { mortem }\end{array}$ & Genital tract carcinomas & $\begin{array}{l}\text { Genotype, persistent } \\
\text { organic pollutants and } \\
\text { herpesvirus }\end{array}$ & $\begin{array}{l}\text { Since the urogenital carcinoma } \\
\text { affects sub-adult and adult } \\
\text { animals of both sexes (cervix } \\
\text { and vagina of females and the } \\
\text { penis, prepuce and urethra of } \\
\text { males) it could potentially alter } \\
\text { reproduction and LH strategies } \\
\text { of seals }\end{array}$ & $\begin{array}{l}\text { Browning et al. } \\
\text { (2015) }\end{array}$ \\
\hline
\end{tabular}

$2 \%$ mortality of birds, with occasional losses of

2-3 year-old

individuals 


\section{Costs on LH traits}

Parasitic organisms exploit their host for resources that could otherwise be used for maintenance, growth and/or reproduction (Poulin, 2007; SchmidHempel, 2011). Direct costs resulting from this exploitation can cause inter-individual (or interpopulation) variation in $\mathrm{LH}$ traits such as fecundity and survival (Thomas et al. 2000). At the same time, inter-individual differences in physiology and LH productivity may 'drive' or encourage consistent variation in behaviour (Biro and Stamps, 2008; Biro et al. 2014), and differences in behaviour can in turn affect the likelihood of encounter rates with parasites and transmission of them between one another (Boyer et al. 2010; Dunn et al. 2011; Bull et al. 2012; Seaman and Briffa, 2015). Thus, inter-individual (or interpopulation) variation in $\mathrm{LH}$ traits could at the same time be both causes and consequences of parasitism. Additionally, direct modifications of the host's LH traits may also result from toxic products of the parasite's metabolism (Michalakis, 2009). Finally, the complex machinery constituting the immune system often incurs metabolic costs that indirectly generate modifications of the host's LH traits as a result of trade-offs (Sorci et al. 2009). The extent to which these trade-offs are manifest are likely to differ among individuals that differ in their energetic and productive capacities (van Noordwijk and de Jong, 1986; Reznick et al. 2000; Biro and Stamps, 2008).

In the context of malignancies, the time elapsing from the appearance of the first cancerous cells to the development of a metastatic cancer may vary from weeks to years, or even decades, depending on individuals and types of cancer. The shape of the relationship between health/fitness-related traits and tumour development is not precisely known for most species and most cancers (see Vittecoq et al. 2015). Nonetheless, individuals harbouring tumours are likely to be, sooner or later, in a worse condition than healthy individuals on average, even if individuals differ in their intrinsic energetic and LH capacities. Frequent symptoms of cancer are extreme tiredness (fatigue) or weight loss, resulting from cancer cells using up much of the body's energy supply, or releasing substances that modify the way the body derives energy from food (Wagner and Cella, 2004; Ryan et al. 2007). Although cancer-related fatigue is one of the most prevalent symptoms in cancer sufferers, the precise aetiology of this distressing and debilitating symptom remains poorly understood. Given that energy allocation relative to energy acquisition is at the heart of predictions for how competing $\mathrm{LH}$ traits might be affected by such energy 'drains' (van Noordwijk and de Jong, 1986), a research focus on energetics might thus be very informative for understanding $\mathrm{LH}$ responses to cancer.

\section{Plastic adjustments of LH traits}

Host LH traits can undergo flexible and adaptive responses to parasitism in order to compensate for the negative costs exerted by parasites on host fitness (Hochberg et al. 1992; Michalakis and Hochberg, 1994). For instance, hosts unable to resist infection by other means (e.g. immunological resistance, inducible defences or long-distance migration) are theoretically favoured by selection if they partly compensate the parasite-induced losses by reproducing earlier (Forbes, 1993) or if their behaviour impedes the transmission of the parasite in spatially structured contexts (Débarre et al. 2012). Infected individuals may, for instance, increase their reproductive activities before dying or being castrated by parasites (Minchella and Loverde, 1981; Sorci et al. 1996; Polak and Starmer, 1998; Adamo, 1999), or simply increase their fitness through kin selection-mediated effects (Débarre et al. 2012; Iritani and Iwasa, 2014). Among recent examples, Vézilier et al. 2015 demonstrated that female mosquitoes parasitized by $P$. falciparum begin laying their eggs two days earlier, thereby compensating the loss of fecundity due to their reduced lifespan. In the context of cancer, preliminary results (Arnal et al. unpublished data) suggest that females in Drosophila harbouring early stages of tumours tend to reach the peak of oviposition earlier than healthy females before concomitantly dying sooner. As compelling as these recent studies are, clearly additional studies of this kind are necessary before generalizations can be made.

\section{Parental 'programming' and inheritance of LH traits}

The influence of parental (non-genetic) effects on their offspring's phenotype is increasingly acknowledged as an important adaptive mechanism in animals (Mousseau et al. 2009; Wolf and Wade, 2009). There is a growing body of evidence indicating that parasitic exploitation of a host can lead to changes in the phenotype of the hosts' offspring, though the latter are not parasitized (reviewed by Poulin and Thomas, 2008). For instance, animals infected with harmful parasites often produce smaller offspring because parents cannot allocate sufficient energy to reproduction (e.g. Hakkarainen et al. 2007; Gallizzi et al. 2008). Additionally, paternal stress can affect offspring phenotype by altering sperm phenotype and affecting post-zygotic development and performance (Crean et al. 2012, 2013; Rando, 2012; Bromfield et al. 2014; Zajitschek et al. 2014). Several proximate mechanisms have been put forward to explain parental effects due to infections, most involving hormonal or other physiological pathways, as well as epigenetic phenomena, and ultimately leading to offspring that are pre-adapted to the parasites they are most 
likely to encounter based on their parent's experience (Sorci and Clobert, 1995).

Are there consequences of having 'cancerous' parents? Given that most if not all individuals among metazoan species accumulate precancerous lesions and in situ tumours in many organs as they age (Folkman and Kalluri, 2004), this question is relevant to virtually all multicellular organisms. Few cancers are directly transmissible, so the risk of offspring contagion is often not applicable. However, because of the health consequences associated with tumourigenesis, parents with more or less advanced malignancies are likely to be affected in their ability to provide adequate resources/parental care to their offspring. To our knowledge this question has never been empirically addressed. As for parasites, deeper trans-generational effects probably exist, as suggested by several studies indicating that epigenetic modifications that influence cancer risk can be inherited through the germline across multiple generations (reviewed in Fleming et al. 2008). Similar to infections, cancer risk could be correlated within families across generations. This should presumably be the case in species with low dispersal, living in areas (naturally or artificially) contaminated by mutagenic substances, because both parents and offspring experience the same ecological contexts. Similarly, the same should apply to cancer caused by inherited oncogenic vulnerabilities. At the moment there is little evidence available on the consequences of having parents harbouring tumours and/or oncogenic mutations on offspring phenotype, in terms of costs and adaptive (nongenetic) transgenerational effects.

Although parent-to-offspring transmission of cancer cells may be uncommon, parent-to-offspring transmission of infections that induce cancer appear to be moderately common (Ewald and Swain Ewald, 2015). For example, in humans, T-lymphotropic virus type 1 (Coovadia et al. 2007) and potentially hepatitis B virus are transmissible to offspring in milk (but see Chen et al. 2013) and cause cancer in a substantial proportion of those offspring (Ewald and Swain Ewald, 2015). In captive wildlife, vertical transmission of simian T-lymphotropic viruses in apes (Parrish et al. 2004; d'Offay et al. 2007), feline immunodeficiency virus in cats (O'Neil et al. 1995) and mouse mammary tumour virus in mice (Bentvelzen et al. 1970) is known, but their occurrence in the wild requires further study.

\section{Evolutionary change in the host population}

Whenever there is a genetic basis to LH traits, or trade-offs between them, evolutionary change in the host population can occur in response to 'infection' by cancer just as it would with parasites. For instance, selection may favour early sexual maturity when the risk of future infection and mortality is high. Indeed, snails from localities with a high prevalence of castrating trematodes become sexually mature earlier than conspecifics living in areas of low prevalence (Lafferty, 1993; Fredensborg and Poulin, 2006). One of the best examples of altered LH strategies in response to exposure to cancer involves the Tasmanian devils (Sarcophilus harrisii) and their transmissible cancer, the devil facial tumour disease (DFTD). Following the appearance of DFTD, devils have responded to the cancerinduced mortality by rapidly transitioning from a late maturing iteroparous (multiple reproductive cycles) to an early maturing semelparous (single breeding) reproductive strategy (Jones et al. 2008).

\section{Concluding remarks}

Is it justifiable to ignore $\mathrm{LH}$ traits when studying oncogenic phenomena? In the light of this discussion, we suggest that the answer is clearly no. Cancer can directly affect LH traits by imposing costs and/or indirectly by triggering plastic adjustments and evolutionary responses, just as parasites are well known to do. Reciprocally, these effects can potentially influence cancer risks, through the evolution of differential cancer vulnerabilities in populations (e.g. Kokko and Hochberg, 2015). For instance, BRCA1 and BRCA2 mutations are inherited and predispose women to breast and ovarian cancer, but even though carriers of these mutations have a reduced survival, they also have enhanced fertility (Easton et al. 1995; Smith et al. 2012). This result may indicate antagonistic pleiotropy (i.e. when one gene controls more than one trait, at least one of these traits is beneficial to the organism's fitness and at least one is detrimental to fitness). However, since the adaptive response by the host also favours the transmission of BRCA1 and BRCA2 to the next generations, this suggests that the existence of $\mathrm{LH}$ trait adjustments could influence the persistence of oncogenic mutations in certain populations. In addition, such adjustments would be, in our opinion, a potentially more parsimonious alternative to the antagonistic pleiotropy hypothesis classically invoked to explain why oncogenic mutations persist at a higher frequency than expected by the mutation-selection balance (e.g. Bodmer, 2006; Risch et al. 2006).

To understand the evolution of LH traits in a cancer context, one must consider the complete ecological context in which individuals developing tumours live. Unfortunately, there is only limited data to date, supporting the hypotheses we have outlined above (Table 1). Clearly more data and research, including on the assumptions of cancers potentially affecting fitness related traits, are needed to draw a more substantiated parallel between cancer and infectious diseases. Because one single method or model cannot thoroughly integrate all the complexity of 
the processes we have discussed, researchers interested in these adaptive responses must engage in greater exchanges and collaborations involving scientists from different disciplines. Finally, we strongly encourage researchers to systematically explore the myriad of symptoms displayed by cancerous patients in order to discover those that could be LH trait responses, ws those that illustrate pathological costs without adaptive value.

\section{ACKNOWLEDGEMENTS}

Frédéric THOMAS and Benjamin ROCHE are supported by the ANR (Blanc project EVOCAN) and by the CNRS (INEE). The CREEC extend their gratitude to its two sponsor companies: SPALLIAN and NEMAUSYS.

\section{REFERENCES}

Adamo, S. (1999). Evidence for adaptive changes in egg laying in crickets exposed to bacteria and parasites. Animal Behaviour 57, 117-124.

Aktipis, C. A. and Nesse, R. M. (2013). Evolutionary foundations for cancer biology. Evolutionary Applications 6, 144-159.

Balls, M. (1962). Spontaneous neoplasms in amphibia: a review and descriptions of six new cases. Cancer Research 22, 1142e1154.

Bentvelzen, P., Daams, J. H., Hageman, P. and Calafat, J. (1970). Genetic transmission of viruses that incite mammary tumor in mice. Proceedings of the National Academy of Sciences of the United States of America 67, 377-384.

Biro, P. A. and Stamps, J. A. (2008). Are animal personality traits linked to life-history productivity? Trends in Ecology and Evolution 23, 361-368. Biro, P. A., Adriaenssens, B. and Sampson, P. (2014). Individual and sex-specific differences in intrinsic growth rate covary with consistent individual differences in behaviour. Fournal of Animal Ecology 83, 1186-1195. Bodmer, W.F. (2006). Cancer genetics: colorectal cancer as a model. Fournal of Human Genetic 51, 391-396.

Boyer, N., Réale, D., Marmet, J., Pisanu, B. and Chapuis, J. L. (2010). Personality, space use and tick load in an introduced population of Siberian chipmunks Tamias sibiricus. Fournal of Animal Ecology 79, 538-547.

Brill, R. W., Balazs, G. H., Holland, K. N., Chang, R. K. C., Sullivan, S. and George, J. C. (1995). Daily movements, habitat use, and submergence intervals of normal and tumor-bearing juvenile green turtles (Chelonia mydas) within a foraging area in the Hawaiian Islands. fournal of Experimental Marine Biology and Ecology 185, 203e218.

Bromfield, J. J., Schjenken, J. E., Chin, P. Y., Care, A. S., Jasper, M. J. and Robertson, S. A. (2014). Maternal tract factors contribute to paternal seminal fluid impact on metabolic phenotype in offspring. Proceedings of the National Academy of Sciences of the United States of America 111, 2200-2205. Browning, H. M., Gulland, F. M. D., Hammond, J. A., Colegrove, K. M. and Hall, A. J. (2015). Common cancer in a wild animal: the California sea lion (Zalophus californianus) as an emerging model for carcinogenesis. Philosophical Transactions of the Royal Society B 370, 20140228 Published 8 June 2015.

Bull, C., Godfrey, S. and Gordon, D. (2012). Social networks and the spread of Salmonella in a sleepy lizard population. Molecular Ecology 21, 4386-4392.

Caulin, A. F. and Maley, C. C. (2011). Peto's Paradox: evolution's prescription for cancer prevention. Trends in Ecology \& Evolution 26, 175-182. Chaloupka, M., Balazs, G. H. and Work, T. M. (2009). Rise and fall over 26 years of a marine epizootic in Hawaiian green sea turtles. Fournal of Wildlife Diseases 45, 1138e 1142 .

Chen, X., Chen, J., Wen, J., Xu, C., Zhang, S., Zhou, Y. H. and Hu, Y. (2013). Breastfeeding is not a risk factor for mother-to-child transmission of Hepatitis B Virus. PLoS ONE 8, e55303.

Ciocan, C. and Sunila, I. (2005). Disseminated neoplasia in blue mussels, Mytilus galloprovincialis, from the Black Sea, Romania. Marine Pollution Bulletin 50, 1335e1339. http://dx.doi.org/10.1016/j.marpolbul.2005.04.042. Ciocan, C. M., Moore, J. D. and Rotchell, J. M. (2006). The role of ras gene in the development of haemic neoplasia in Mytilus trossulus. Marine Environmental Research 62, S147eS150. http://dx.doi.org/10.1016j.marenvres.2006.04.020.
Coovadia, H. M., Rollins, N. C., Bland, R. M., Little, K., Coutsdoudis, A., Bennish, M. L. and Newell, M. L. (2007). Motherto-child transmission of HIV-1 infection during exclusive breastfeeding in the first 6 months of life: an intervention cohort study Lancet 369, 1107-1116.

Crean, A. J., Dwyer, J. M. and Marshall, D. J. (2012). Fertilization is not a new beginning: the relationship between sperm longevity and offspring performance. PLoS ONE 7, e49167.

Crean, A. J., Dwyer, J. M. and Marshall, D. J. (2013). Adaptive paternal effects? Experimental evidence that the paternal environment affects offspring performance. Ecology 94, 2575-2582.

Débarre, F., Lion, S., van Baalen, M. and Gandon, S. (2012). Evolution of host life-history traits in a spatially structured host-parasite system. The American Naturalist 179, 52-63.

Domazet-Loso, T., Klimovich, A., Anokhin, B., Anton-Erxleben, F., Hamm, M. J., Lange, C. and Bosch, T. C. G. (2014). Naturally occurring tumours in the basal metazoan Hydra. Nature Communications 5, 1-8. d'Offay, J. M., Eberle, R., Sucol, Y., Schoelkopf, L., White, M. A., Valentine, B. D., White, G. L. and Lerche, N. W. (2007). Transmission dynamics of simian T-lymphotropic virus type 1 (STLV1) in a baboon breeding colony: predominance of female-to-female transmission. Comparative Medicine 57, 105-114.

Duesberg, P., Mandrioli, D., McCormack, A. and Nicholson, J. M. (2011). Is carcinogenesis a form of speciation? Cell Cycle 10, 2100-2114. Dunn, J. (2013). Lymphoid Leukosis in Poultry. http://www.merckvet manual.com/mvm/poultry/neoplasms/lymphoid_leukosis_in_poultry.html Dunn, J. C., Cole, E. F. and Quinn, J. L. (2011). Personality and parasites: sex-dependent associations between avian malaria infection and multiple behavioural traits. Behavioral Ecology and Sociobiology 65, 1459-1471.

Easton, D. F., Ford, D. and Bishop, D. T. (1995). Breast and ovarian cancer incidence in BRCA1-mutation carriers. Breast cancer linkage consortium. American fournal of Human Genetics 56, 265-271.

Ewald, P. W. and Swain Ewald, H. A. (2012). Infection, mutation, and cancer evolution. Fournal of Molecular Medicine 90, 535-541.

Ewald, P. W. and Swain Ewald, H. A. (2013). Toward a general evolutionary theory of oncogenesis. Evolutionary Applications 6, 70-81.

Ewald, P. W. and Swain Ewald, H. A. (2014). Joint infectious causation of human cancers. Advances in Parasitology 84, 1-26.

Ewald, P. W. and Swain Ewald, H. A. (2015). Infection and cancer in multicellular organisms. Philosophical Transactions of the Royal Society B 370, 1-11

Fleming, J. L., Huang, T. H. and Toland, A. E. (2008). The role of parental and grandparental epigenetic alterations in familial cancer risk. Cancer Research 68, 9116-9121.

Folkman, J. and Kalluri, R. (2004). Cancer without disease. Nature 427, $787-787$.

Forbes, M. R. L. (1993). Parasitism and host reproductive effort. Oikos 67, 444-450.

Fredensborg, B. L. and Poulin, R. (2006). Parasitism shaping host lifehistory evolution: adaptive responses in a marine gastropod to infection by trematodes. Fournal of Animal Ecology 75, 44-53.

Gallizzi, K., Alloitteau, O., Harrang, E. and Richner, H. (2008). Fleas, parental care, and transgenerational effects on tick load in the great tit. Behavioral Ecology 19, 1225-1234.

Galimany, E. and Sunila, I. (2008). Several cases of disseminated Neoplasia in Mussels Mytilus edulis (L.) in western long island sound. Fournal of Shellfish Research 27, 1201-1207.

Goyos, A. and Robert, J. (2009). Tumorigenesis and anti-tumor immune responses in Xenopus. Frontiers in Bioscience: A fournal and Virtual Library 14, $167 \mathrm{e} 176$.

Gyimesi, Z.S., Garner, M. M., Burns, R. B., Nichols, D. K., Brannian, R.E., Raymond, J. T. and Nordhausen, R. (2005). High incidence of lymphoid Neoplasia in a colony of Egyptian spiny-tailed lizards (Uromastyx aegyptius). Fournal of Zoo and Wildlife Medicine 36, 103-110.

Hakkarainen, H., Huhta, E., Koskela, E., Mappes, T., Soveri, T. and Suorsa, P. (2007). Eimeria-parasites are associated with a lowered mother's and offspring's body condition in island and mainland populations of the bank vole. Parasitology 134, 23-31.

Hart, B. (1994). Behavioural defence against parasites: interaction with parasite invasiveness. Parasitology 109, S139-S151.

Hardwick, L. J. A. and Philpott, A. (2015). An oncologis's friend: how Xenopus contributes to cancer research. Developmental Biology 408, 180-187. Hochberg, M. E., Michalakis, Y. and de Meeus, T. (1992). Parasitism as a constraint on the rate of life-history evolution. Fournal of Evolutionary Biology 5, 491-504. 
Iritani, R. and Iwasa, Y. (2014). Parasite infection drives the evolution of state-dependent dispersal of the host. Theoretical Population Biology 92, $1-13$.

Jones, M. E., Cockburn, A., Hamede, R., Hawkins, C., Hesterman, H., Lachish, S., Mann, D., McCallum, H. and Pemberton, D. (2008). Life-history change in disease-ravaged Tasmanian devil populations. Proceedings of the National Academy of Sciences of the United States of America 105, 10023-10027.

Kokko, H. and Hochberg, M. E. (2015). Towards cancer-aware lifehistory modelling. Philosophical Transactions of the Royal Society of London B, Biological Sciences 370, 20140234.

Lafferty, K. D. (1993). The marine snail, Cerithidea californica, matures at smaller sizes where parasitism is high. Oikos 68, 3-11.

LePage, V., Dutton, C. J., Kummrow, M., McLelland, D. J., Young, K. and Lumsden, J. S. (2012). Neoplasia of captive yellow sea horses (Hippocampus kuda) and weedy sea dragons (Phyllopteryx taeniolatus). Fournal of Zoo and Wildlife Medicine 43, 50-58.

Mager, D. (2006). Bacteria and cancer: cause, coincidence or cure? A review. Fournal of Translational Medicine 4, 14.

Martineau, D., Lemberger, K., Dallaire, A., Labelle, P., Lipscomb, T. P., Michel, P. and Mikaelian, I. (2002). Cancer in wildlife, a case study: beluga from the St. Lawrence estuary, Quebec, Canada. Environmental Health Perspectives 110, 285.

McAloose, D. and Newton, A. L. (2009). Wildlife cancer: a conservation perspective. Nature Reviews Cancer 9, 517-526.

McCallum, H., Tompkins, D. M., Jones, M., Lachish, S., Marvanek, S., Lazenby, B., Hocking, G., Wiersma, J. and Hawkins, C. E. (2007). Distribution and impacts of tasmanian devil facial tumour disease. Ecohealth 4, 318-325.

Merlo, L. M. F., Pepper, J. W., Reid, B. J. and Maley, C. C. (2006). Cancer as an evolutionary and ecological process. Nature Reviews Cancer 6, 924-935.

Metzger, M. J., Reinisch, C., Sherry, J. and Goff, S.P. (2015). Horizontal transmission of clonal cancer cells causes leukemia in softshell clams. Cell 161, 255-263.

Michalakis, Y. (2009). Parasitism and the evolution of life-history traits. In Ecology and Evolution of Parasitism (ed. Thomas, F., Guégan, J.-F. and F. R.), pp. 19-30. Oxford University Press, New York.

Michalakis, Y. and Hochberg, M. E. (1994). Parasitic effects on host life-history traits: a review of recent studies. Parasite 1, 291-294.

Minchella, D. and Loverde, P. (1981). A cost of increased early reproductive effort in the snail Biomphalaria glabrata. American Naturalist 118, 876-881.

Molyneux, E. M., Rochford, R., Griffin, B., Newton, R., Jackson, G., Menon, G., Harrison, C. J., Israels, T. and Bailey, S. (2012). Burkitt's lymphoma. Lancet 379, 1234-1244.

Mostafa, M. H., Sheweita, S. A. and O'Connor, P. J. (1999). Relationship between Schistosomiasis and Bladder Cancer. Clinical Microbiology Reviews 12, 97-111.

Moriarty, M.E., Vickers, T.W., Clifford, D. L., Garcelon, D. K., Gaffney, P.M., Lee, K.W., King, J.L., Duncan, C. L. and Boyce, W. M. (2015). Ear mite removal in the Santa Catalina Island Fox (Urocyon littoralis catalinae): controlling risk factors for cancer development. PLoS ONE 10, e0144271.

Mousseau, T. A., Uller, T., Wapstra, E. and Badyaev, A. V. (2009). Evolution of maternal effects: past and present. Philosophical Transactions of the Royal Society of London B, Biological Sciences 364, 1035-1038.

Nunney, L. (2013). The real war on cancer: the evolutionary dynamics of cancer suppression. Evolutionary Applications 6, 11-19.

O'Neil, L. L., Burkhard, M. J., Diehl, L. J. and Hoover, E. A. (1995). Vertical transmission of feline immunodeficiency virus. AIDS Research and Human Retroviruses 11, 171-182.

Page-Karjian, A., Norton, T. M., Krimer, P., Groner, M., Nelson, S. E., Jr. and Gottdenker, N. L. (2014). Factors influencing survivorship of rehabilitating green sea turtles (Chelonia mydas) with fibropapillomatosis. fournal of Zoo and Wildlife Medicine 45, 507-519.

Parrish, S. W. K., Brown, A. E., Chanbancherd, P., Gettayacamin, M. and Parrish, J. H. (2004). Transmission of STLV in a closed colony of macaques. American fournal of Primatology 63, 103-109.

Polak, M. and Starmer, W. T. (1998). Parasite-induced risk of mortality elevates reproductive effort in male Drosophila. Proceedings Biological Sciences/The Royal Society 265, 2197-2201.

Poulin, R. (2007). Evolutionary Ecology of Parasites, 2nd Edn. Princeton University Press, Princeton.

Poulin, R. and Thomas, F. (2008). Epigenetic effects of infection on the phenotype of host offspring: parasites reaching across host generations. Oikos 117, 331-335.
Rando, O. J. (2012). Daddy issues: paternal effects on phenotype. Cell 151, 702-708.

Reznick, D., Nunney, L. and Tessier, A. (2000). Big houses, big cars, superfleas and the costs of reproduction. Trends in Ecology and Evolution 15, 421-425.

Risch, H. A., McLaughlin, J. R., Cole, D. E. C., Rosen, B., Bradley, L., Fan, I., Tang, J., Li, S., Zhang, S., Shaw, P. A. and Narod, S. A. (2006) Population BRCA1 and BRCA2 mutation frequencies and cancer penetrances: a kin-cohort study in Ontario, Canada. Fournal of the National Cancer Institute 98, 1694-1706.

Roche, B., Hochberg, M. E., Caulin, A.F., Maley, C. C. Gatenby, R. A., Missé, D. and Thomas, F. (2012). Natural resistance to cancers: a Darwinian hypothesis to explain Peto's paradox. BMC Cancer 12, 387.

Rozhok, A. I. and DeGregori, J. (2015). Toward an evolutionary model of cancer: considering the mechanisms that govern the fate of somatic mutations. Proceedings of the National Academy of Sciences of the United States of America 112, 8914-8921.

Ryan, J. L., Carroll, J. K., Ryan, E.P., Mustian, K. M., Fiscella, K. and Morrow, G. R. (2007). Mechanisms of cancer-related fatigue. The Oncologist 12 (Suppl. 1), 22-34.

Salomon, R. N. and Jackson, F. R. (2008). Tumors of testis and midgut in aging flies. Fly 2, 265e268.

Schmid-Hempel, P. (2011). Evolutionary Parasitology: The Integrated Study of Infections, Immunology, Ecology, and Genetics. Oxford University Press, Oxford.

Shimonohara, N., Holland, C. H., Lin, T.-L. and Wigle, W. L. (2012) Naturally occurring neoplasms in pigeons in a research colony: a retrospective study. Avian Diseases 57, 133e139. http://dx.doi.org/10.1637/ 10244-051012-Case.1.

Seaman, B. and Briffa, M. (2015). Parasites and personality in periwinkles (Littorina littorea): infection status is associated with mean-level boldness but not repeatability. Behavioural Processes 115, 132-134.

Smith, K. R., Hanson, H. A., Mineau, G.P. and Buys, S. S. (2012) Effects of BRCA1 and BRCA2 mutations on female fertility. Proceedings of the Royal Society B, Biological Sciences 279, 1389-1395.

Sorci, G. and Clobert, J. (1995). Effects of maternal parasite load on offspring life-history traits in the common lizard (Lacerta vivipara). Fournal of Evolutionary Biology 8, 711-723.

Sorci, G., Clobert, J. and Michalakis, Y. (1996). Cost of reproduction and cost of parasitism in the common lizard, Lacerta vivipara. Oikos $\mathbf{7 6}$ 121-130.

Sorci, G., Boulinier, T., Gauthier-Clerc, M. and Faivre, B. (2009). The evolutionary ecology of the immune response. In Ecology and Evolution of Parasitism (ed. by Thomas, F., Guégan, J.F., and Renaud, F.), pp. 5-17. Oxford University Press, Oxford.

Sweet, M., Kirkham, N., Bendall, M., Currey, L., Bythell, J. and Heupel, M. (2012). Evidence of melanoma in wild marine fish populations. PLoS ONE 7, e41989.

Thomas, F., Guégan, J., Michalakis, Y. and Renaud, F. (2000). Parasites and host life-history traits: implications for community ecology and species co-existence. International Fournal for Parasitology 30, 669-674.

Thomas, F., Guégan, J.-F. and Renaud, F. (2009). Ecology and Evolution of Parasitism. Oxford University Press.

Thomas, F., Fisher, D., Fort, P., Marie, J.-P., Daoust, S., Roche, B., Grunau, C., Cosseau, C., Mitta, G., Baghdiguian, S., Rousset, F., Lassus, P., Assenat, E., Grégoire, D., Missé, D., Lorz, A., Billy, F., Vainchenker, W., Delhommeau, F., Koscielny, S., Itzykson, R., Tang, R., Fava, F., Ballesta, A., Lepoutre, T., Krasinska, L., Dulic, V., Raynaud, P., Blache, P., Quittau-Prevostel, C. et al. (2013). Applying ecological and evolutionary theory to cancer: a long and winding road. Evolutionary Applications 6, 1-10.

van Noordwijk, A. J. and de Jong, G. (1986). Acquisition and allocation of resources: their influence on variation in life history tactics. The American Naturalist 128, 137-142.

Vézilier, J., Nicot, A., Gandon, S. and Rivero, A. (2015). Plasmodium infection brings forward mosquito oviposition. Biology Letters 11(3), 20140840. doi: 10.1098/rsbl.2014.0840.

Vickers, T. W., Clifford, D. L., Garcelon, D. K., King, J. L., Duncan, C. L., Gaffney, P. M. and Boyce, W. M. (2015). Pathology and epidemiology of ceruminous gland tumors among endangered Santa Catalina Island foxes (Urocyon littoralis catalinae) in the Channel Islands, USA. PLoS ONE 10, e0143211.

Vittecoq, M., Roche, B., Daoust, S.P., Ducasse, H., Missé, D., Abadie, J., Labrut, S., Renaud, F., Gauthier-Clerc, M. and Thomas, F. (2013). Cancer: a missing link in ecosystem functioning? Trends in Ecology and Evolution 28, 628-635. 
Vittecoq, M., Ducasse, H., Arnal, A., Møller, A.P., Ujvari, B., Jacqueline, C. B., Tissot, T., Missé, D., Bernex, F., Pirot, N., Lemberger, K., Abadie, J., Labrut, S., Bonhomme, F., Renaud, F., Roche, B. and Thomas, F. (2015). Animal behaviour and cancer. Animal Behaviour 101, 19-26.

Wagner, L. I. and Cella, D. (2004). Fatigue and cancer: causes, prevalence and treatment approaches. British Fournal of Cancer 91, 822-828.
Wolf, J. B. and Wade, M. J. (2009). What are maternal effects (and what are they not)? Philosophical Transactions of the Royal Society of London $B$, Biological Sciences 364, 1107-1115.

Zajitschek, S., Hotzy, C., Zajitschek, F. and Immler, S. (2014). Shortterm variation in sperm competition causes sperm-mediated epigenetic effects on early offspring performance in the zebrafish. Proceedings of the Royal Society of Sciences B 281, 20140422. 